\title{
THE EFFECT OF SOME PHYSIOLOGICAL VARIABLES ON THE NUMBER OF CASTS, RED BLOOD CELLS AND WHITE BLOOD CELLS AND EPITHELIAL CELLS IN THE URINE OF NORMAL INDIVIDUALS*
}

\author{
By T. ADDIS \\ (From the Medical Department of Stanford University Medical Sciool, San Francisco)
}

(Received for publication March 8, 1926)

In the course of clinical work with patients suffering from Bright's disease certain questions constantly present themselves which as constantly are left unanswered except by practical decisions of an almost completely arbitrary nature. For instance, how long should a patient be kept in bed when the initial stage of haemorrhagic Bright's disease has passed, when the edema has gone and the blood pressure has returned to its usual level? Certainly until examinations of the urinary sediment indicate a subsidence in the first intensity of the inflammatory process in the kidney, but also quite certainly not until all signs of inflammation have disappeared, since the latent stage of the disease extends over months or years or decades and during all this time the urine indicates the continuance of an active renal inflammation. If a pronounced increase in the number of casts, red blood cells and white blood cells and epithelial cells were observed after the patient was first out of bed, we might feel fairly certain that further rest was necessary, but it is impossible to interpret the significance of a moderate or slight increase. We know nothing about the response of the normal kidney to like conditions. It may be that some degree of increase in casts and red blood cells is the natural reaction of the kidney to the slight jars and jolts which it receives with every movement of the body. Again, in the treatment of the actively inflammatory types of Bright's disease it has for long been the custom to reduce the quantity of protein in,

*This work was aided by the Wellington Gregg Fund for the investigation of Bright's Disease. 
the food to a minimum, because the work of the kidney is thereby lessened and rest has been found efficacious in the treatment of inflammation in general. However there are special reasons for hesitancy in accepting conclusions drawn by analogy from observations on other organs as necessarily true for the kidney, and in actual fact the effects of protein on the kidney are still the subject of experiment and disagreement. Direct evidence might be obtained by observing the effect of large amounts of protein on the urinary sediment of patients with Bright's disease but a prerequisite is a knowledge of the changes which may thus be produced in the urine of normal individuals. An attempt was therefore made to estimate the influence on the urinary sediment of medical students of certain types of bodily movement and also to obtain a measure of the effect of the administration of a large quantity of protein.

TABLE 1

The rate of excretion of formed elements during the day compared with the rate of excretion during the night

Averages from a group of 18 individuals

\begin{tabular}{c|c|c|c|c|c}
\hline \multicolumn{2}{c|}{ Casts } & \multicolumn{2}{|c|}{$\begin{array}{c}\text { Red blood cells } \\
\text { per 12 hours }\end{array}$} & \multicolumn{2}{|c|}{$\begin{array}{c}\text { White and epithelial cells } \\
\text { per 12 hours }\end{array}$} \\
\hline Day & Night & Day & Night & Day & Night \\
\hline 852 & 827 & 48,900 & 65,600 & 434,000 & 259,000 \\
\hline
\end{tabular}

\section{DAY AND NIGHT URINES}

A group of 18 students collected urine from 8:30 p.m. to 8:30 a.m. (night urine) and from 8:30 a.m. to 12:30 p.m. (day urine). In both cases the results are expressed as 12-hour rates. No fluids were taken for 24 hours so that the urine might be concentrated. The night urine had an average volume of $382 \mathrm{cc}$. with a specific gravity of 1.029 . It is of interest that the day volume, though secreted during the last 4 hours of the period of abstention from fluids, had a larger volume -522 cc. per 12-hour period with a specific gravity of 1.029 . The average counts are given in table 1.

On account of the great variability in the rates of excretion of the various formed elements of the urine the difference between group averages must be large to be significant. In this instance the actual 
differences observed might well have been the result of chance and we must conclude that no appreciable difference has been shown to exist between the day and night sediments.

\section{EFFECT OF VIBRATION}

Since the ordinary day time activities were without effect, another experiment was carried through in which a more directly traumatic influence on the kidney was introduced. The subjects sat on a chair

TABLE 2

The effect of shaking on a vibrating chair

Averages from a group of 9 individuals

\begin{tabular}{c|c|c|c|c|c}
\hline \multicolumn{2}{c|}{$\begin{array}{c}\text { Casts } \\
\text { per 12 hours }\end{array}$} & \multicolumn{2}{c|}{$\begin{array}{c}\text { Red blood cells } \\
\text { per 12 hours }\end{array}$} & \multicolumn{2}{c}{$\begin{array}{c}\text { White and epithelial cells } \\
\text { per 12 hours }\end{array}$} \\
\cline { 2 - 6 } No shaking & Shaking & No shaking & Shaking & No shaking & Shaking \\
\hline 582 & 378 & 70,700 & 212,100 & 313,000 & 587,000 \\
\hline
\end{tabular}

TABLE 3

The rate of red blood cell excretion without and with shaking

\begin{tabular}{|c|c|c|}
\hline Name & $\begin{array}{l}\text { No shaking } \\
\text { per } 12 \text { hours }\end{array}$ & $\begin{array}{l}\text { Shaking } \\
\text { per } 12 \text { hours }\end{array}$ \\
\hline 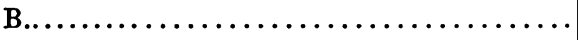 & 87,000 & 291,000 \\
\hline 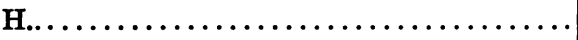 & 120,000 & 144,900 \\
\hline W.................... & 27,000 & 202,800 \\
\hline 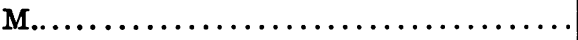 & 44,400 & 291,000 \\
\hline McB................. & 0 & 56,400 \\
\hline 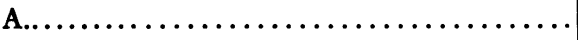 & $\mathbf{0}$ & 0 \\
\hline 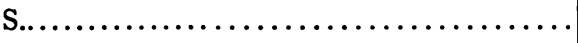 & 237,900 & 558,000 \\
\hline 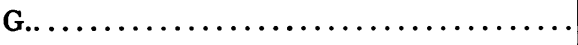 & 66,000 & 30,000 \\
\hline 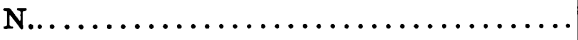 & 54,000 & 336,000 \\
\hline
\end{tabular}

which rested on steel springs and which was shaken by a motor. In this manner strong vibrating movements were transmitted to them not unlike those experienced in riding on a motor-bicycle. Half an hour was as much as could be tolerated without too much discomfort. Collections of urine were made from 8:30 a.m. to 12:30 p.m after abstention from fluids during the preceding day. The shaking extended from 8:30 a.m to 9:00 a.m. The average results expressed as 12-hour rates are given in table 2 . 
The greatest difference is a threefold increase in the number of red blood cells after shaking. The individual counts (table 3) show a fairly well distributed increase after shaking and at first glance it would seem that a quite definite effect had been produced. But the "probable difference between the averages" of the two series is not much less than the actual difference, and this result might therefore be a chance. It may accordingly be concluded that vibration did not lead to a significant increase in any of the formed elements in the urine.

III. THE EFFECT OF THE ADMINISTRATION OF A LARGE AMOUNT OF MEAT

A group of 25 students took $1 \frac{1}{2}$ pounds of steak at $6: 30$ p.m. and collected urine from 8:30 p.m. until 8:30 a.m. No fluids were taken

TABLE 4

The effect of the administration of a large amount of meat

Averages from a group of 25 individuals

\begin{tabular}{c|c|c|c|c|c}
\multicolumn{2}{c|}{$\begin{array}{c}\text { Casts } \\
\text { per 12 hours }\end{array}$} & \multicolumn{2}{c|}{$\begin{array}{c}\text { Red blood cells } \\
\text { per 12 hours }\end{array}$} & \multicolumn{2}{c}{$\begin{array}{c}\text { White and epithelial cells } \\
\text { per 12 hours }\end{array}$} \\
\hline No meat & Meat & No meat & Meat & No meat & Meat \\
\hline 1,078 & 681 & 45,000 & 165,000 & 309,000 & 244,000 \\
\hline
\end{tabular}

after 12:30 p.m. of the day preceding the completion of the collection. The average results are compared with the control tests in table 4. In the control experiments the average volume was $378 \mathrm{cc}$. with a specific gravity of 1.030. After meat the volume was $479 \mathrm{cc}$. with a specific gravity of 1.033 .

The only difference which might possibly have a meaning is the increase in the number of red blood cells after eating the meat. Unfortunately, however, the red blood cells could be counted in only 17 of the 25 observations after meat, because in the remainder there was a deposit of phosphates in the urine. Instead of making the urine more acid, as might have been expected, the ingestion of the meat was followed in these instances by the secretion of an alkaline urine. The fact that meat often causes the urine to become alkaline has already been noted by Lutz (1). The individual data in these 17 comparisons are given in table 5 . 
A simple inspection of table 5 is enough to indicate that there is no proof that the meat was the cause of the observed increase in the average rate of red blood cell excretion, for that increase is accounted for in the main by an unusually large excretion in a single individual. This impression is confirmed by statistical analysis. The "probable difference between the averages" is 205,000 while the actually observed difference is only 120,000 .

TABLE 5

The rate of red blood cell excretion without and with meat

\begin{tabular}{|c|c|c|}
\hline Name & $\begin{array}{l}\text { No meat } \\
\text { per } 12 \text { hours }\end{array}$ & $\begin{array}{c}\text { Meat } \\
\text { per } 12 \text { hours }\end{array}$ \\
\hline H... & 7,300 & 0 \\
\hline ........... & 0 & 0 \\
\hline w...................... & 1,500 & 0 \\
\hline 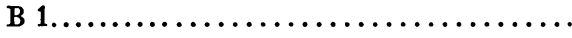 & 0 & 0 \\
\hline в $2 \ldots \ldots \ldots \ldots \ldots \ldots \ldots \ldots \ldots \ldots \ldots \ldots \ldots \ldots \ldots \ldots$ & 0 & 61,000 \\
\hline 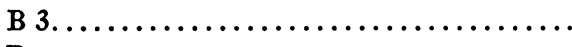 & 0 & 34,000 \\
\hline 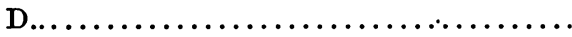 & 2,600 & 0 \\
\hline M................. & 182,000 & 442,000 \\
\hline Ве........, & 0 & 0 \\
\hline 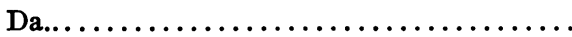 & 0 & 510,000 \\
\hline Gr............... & 4,200 & $1,190,000$ \\
\hline Bu.............. & 276,000 & 27,200 \\
\hline 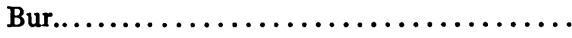 & $\mathbf{0}$ & 0 \\
\hline 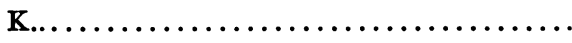 & 0 & 119,000 \\
\hline 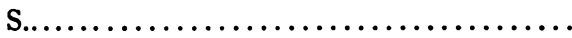 & 208,000 & 63,200 \\
\hline 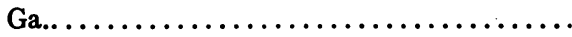 & 56,400 & 272,000 \\
\hline 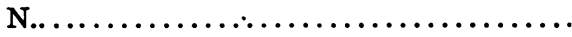 & 22,300 & 89,000 \\
\hline
\end{tabular}

\section{CONCLUSION}

Quantitative determinations of the number of formed elements in the urine of normal individuals failed to show that either bodily movements of various types or the ingestion of a large amount of protein in the form of meat had any statistically significant effect.

\section{BIBLIOGRAPHY}

Lutz, O.: Zeit. f. d. ges. Exp. Med., 1924, xli, 516. 